\title{
THE INCLUSIVE COMMAND: VOLUNTARY INTEGRATION OF SEXUAL MINORITIES INTO THE U.S. MILITARY
}

\author{
Jennifer Gerarda Brown* \& Ian Ayres**
}

\begin{abstract}
"The human heart is the starting point of all matters pertaining to war." - Marshal Maurice de Saxe ${ }^{1}$
\end{abstract}

"What we do and what we think is fascinatingly dependent, much of the time, on what we believe that other people do and think."

- Cass Sunstein ${ }^{2}$

\section{INTRODUCTION}

Many opponents of gays in the military will accept the proposition that gay and lesbian soldiers, ${ }^{3}$ most of them closeted, have served their country bravely and well. General Colin Powell has referred to gay service members as "proud, brave, loyal, good Americans" who have

* Visiting Lecturer and Senior Research Scholar, Yale Law School; Professor of Law and Director, Center on Dispute Resolution, Quinnipiac University School of Law. A.B. 1982, Bryn Mawr; J.D. 1985, University of Illinois. - Ed.

** William K. Townsend Professor, Yale Law School. B.A. 1963, J.D. 1986, Yale; Ph.D. (Economics) 1988, Massachusetts Institute of Technology. - Ed. For helpful comments and conversations, we thank David Cruz, William Eskridge, Barney Frank, Diane Mazur, Linda Meyer, Kenji Yoshino, and workshop participants at UCLA, USC, Colorado, Georgetown, and Australian National universities. Jessica Ballou, Gowri Ramachandran, Eric McGrew, Richard Gora, and Fadi Hanna provided helpful research assistance.

1. Marshal Maurice de Saxe, My Reveries Upon the Art of War (1757), in Roots of Strategy: A Collection OF Military Classics 177 (Brig. Gen. Thomas R. Phillips trans., ed., 1940).

2. Cass R. Sunstein, Situationism, THE NEW RePUBLIC, Mar. 13, 2000, at 42, 46 (reviewing MalCOLM GLADWELL, THE TIPPING POINT: HOW LiTTLE THINGS CAN MAKE A BIG DIFFERENCE (2000)).

3. For simplicity's sake, we will use the terms "gay and lesbian" to refer to sexual minorities of various sorts, especially gay men, lesbians, bisexuals, and transgendered people. We do not mean to treat all sexual minorities monolithically, because important differences might make our proposal more workable for some groups than for others. $C f$. Diane H. Mazur, Re-Making Distinctions on the Basis of Sex: Must Gay Women Be Admitted to the Military Even if Gay Men Are Not?, 58 OHIO ST. L.J. 953 (1997) (arguing that men and women could legitimately receive disparate treatment with respect to the ban on homosexuality in the military). Similarly, and again for simplicity's sake, we will often use the term "soldier" to refer to service members of all branches of the military, and "army" to refer to the military generally.

4. 1993 Defense Budget House Hearing, 102d Cong., at 45 (1993). 
"served well in the past and are continuing to serve well." General $\mathrm{H}$. Norman Schwartzkopf agrees: "homosexuals have served in the past and have done a great job serving their country."

What these opponents find harder to accept is the proposition that heterosexual people can effectively serve their country if openly gay people are in the military with them. The fear is that if openly gay and lesbian people are allowed to serve, they will make other soldiers uncomfortable. This discomfort will cause a breakdown in morale and discipline, destroying the "unit cohesion" that is essential for effective soldiering.

To show that these fears have perpetuated an exclusion policy that is overbroad, this Essay proposes the creation of inclusive commands in the U.S. military. ' Gay and non-gay soldiers would effectively volunteer for inclusive commands by answering "no" to the following question: Would you prefer to serve in a command without any gay personnel? Soldiers who were not willing to serve with gay people would be assigned to alternative, exclusive commands based upon their answer to the sorting question. Placement in an inclusive command would therefore be entirely voluntary. It bears emphasizing that the inclusive command would combine gay and nongay service members. The point of the proposal is not to create a segregated unit just for sexual minorities, for this might reinforce stereotypes and prejudice. A "gay" command would fail to address the unit cohesion problem head on. Therefore, the command should be "inclusive."

This Essay also is an application of the theory of ambiguation, ${ }^{8}$ a concept we borrow from the work of Lawrence Lessig. ${ }^{9}$ Lessig argues that people can deploy rhetorical devices to change a society's shared understanding of the meaning conveyed by a given word or action. One of the rhetorical devices Lessig discusses is "ambiguation," which gives "the particular act, the meaning of which is to be regulated, a second meaning as well, one that acts to undermine the negative effects of the first." 10 The very act of saying that you are willing to

5. S. Hrg. No. 103-845, Ex. JX-1, vol. 3, at 707.

6. Id. at 612 (testimony of Gen. H. Norman Schwartzkopf).

7. A command is any military unit, post, district, or region under the control of one officer. This could be an Air Force base, an Army hospital, or a single submarine. We deliberately use the rather general term "command" here to leave open the many possibilities for implementing our proposal. Some types of commands are easier to integrate than others. A hospital or medical unit even today would contain a higher proportion of openly gay, lesbian, and bisexual service members than an infantry unit in the U.S. Marines.

8. See IAN AYRES \& JENNIFER GERARDa BRown, STRAightForWARD: Mobilizing HETEROSEXUAL SUPPORT FOR GAY RIGHTS, ch. 5 (forthcoming 2005) (discussing the strategy of ambiguation and its applicability to issues of sexual orientation).

9. See Lawrence Lessig, The Regulation of Social Meaning, 62 U. CHI. L. REV. 943, 1010 (1995).

10. Id. 
serve with gay soldiers might make some people wonder whether you yourself are gay. As the set of people who are understood possibly to be gay expands, people's understanding of what it means to be gay also changes, and stereotypes erode.

The inclusive command would challenge some heterosexual soldiers to "come out" as supporters of gay rights and in so doing raise questions about their own sexuality. The fact that soldiers would be forced to answer the question "yea" or "nay" marks a turn toward more uncomfortable choices. Some soldiers might prefer not to have to answer this type of question. But studies show that Americans age 18-29 are less likely than the generation before them to support discrimination on the basis of sexual orientation. Indeed, a large majority of people in this age group believe that gay men and lesbians should be permitted to serve openly in the U.S. military. ${ }^{11}$ When faced with the option, we will ultimately argue, many soldiers today will opt for the inclusive command.

These changing attitudes also suggest an answer to skeptics who might protest that our proposal inappropriately calls for the military to engage in social engineering. The point is that tolerance for homosexuality has grown in American society, particularly among the age group most likely to serve in today's military. Granted, our proposal calls for innovative policy making and some willingness on the part of senior personnel to depart from well-worn rules. The goal is not simply to create new acceptance for sexual minorities, but to demonstrate that this acceptance already exists among large groups of potential recruits.

We explicitly seek incremental progress. To that end, we propose two distinct, intermediate stages on the path toward nondiscrimination. In each stage, the military would ask recruits distinct questions, and the answers would have distinct consequences. The essential difference between the stages of integration is that in stage I, our system would not require any changes in the current "don't ask, don't tell" ("DADT") policy, and soldiers in both types of commands would remain closeted, but in stage II, DADT would be lifted for the inclusive command and service members assigned to that command would be free to speak openly about their sexual orientations.

Let us begin with stage I. All soldiers would be asked two questions:

Question No. 1: Your answer to this first question will be kept confidential (and your answer will have no effect on your future assignments or treatment). Would you be willing to serve in a command with openly gay service personnel?

11. See infra note 90 and accompanying text. 
Question No. 2: Your answer to this second question will not be kept confidential. If you answer "no" you will be assigned to an "inclusive" command. If you answer "yes" you will be assigned to an "exclusive" command. Would you prefer to serve in a command without any gay personnel?

The first question elicits information about whether service members are comfortable serving with openly gay colleagues. Since the answers to this question will be kept confidential, the question is likely to provide feedback on the level of discomfort, which is the premise for the "unit cohesion" concern. It also pushes recruits a bit to consider what they would be "willing" to do - a lower standard than what they might "prefer" to do. The question does not specify the conditions under which the recruit would be "willing" to serve with openly gay people (e.g., is this pursuant to an order or merely a request from commanding officers?). Even recruits who prefer not to serve with openly gay people might respond that they are "willing" to do so under some circumstance they imagine as they answer the question.

The second question asks not about willingness to serve with openly gay people, but about preferences. To answer yes to the second question, a recruit must prefer not to serve with any gay personnel whether openly gay or closeted. On the one hand, the threshold for giving an anti-gay response to this question is lower than for Question 1 , because even recruits who dislike homosexuality and would prefer not to serve with anyone who is gay might be "willing" to serve with openly gay people if asked to do so. On the other hand, Question 2 asks about preferences regarding any gay people, not just openly gay people. Some recruits might be unwilling to serve with openly gay people but neutral regarding service with closeted gay people (thus they would answer "no" to the second question, even though they are not willing to serve with openly gay people). Although this may at first seem a perverse result, on closer examination it is consistent with the function of these questions to channel only the most prejudiced recruits into the exclusive command. Particularly in stage I, when DADT remains in effect even for the inclusive command, recruits who are neutral regarding closeted gay service members belong in the inclusive command.

In stage II of this evolving plan of integration, the statutes and regulations comprising the DADT policy would require amendment to permit but not require gay and lesbian members of inclusive commands to come out. All soldiers would be asked a single question:

Your answer to this question will not be kept confidential. If you answer "yes" you will be assigned to an "inclusive" command. If you answer "no" you will be assigned to an "exclusive" command. 
Would you be willing to serve in a command with openly gay service personnel?

In stage II, DADT would still be in effect for the exclusive command - so that soldiers who wanted to avoid serving with openly gay soldiers could do so. But in the second stage, the inclusive command would become a space in which openly gay and lesbian soldiers could serve their country and willing heterosexual soldiers could serve with them. Even stage II would be an intermediate, evolutionary step in the progression from exclusion, through DADT, to the ultimate goal: mandatory, wholesale integration of sexual minorities into the armed services.

The inclusive command would help to unpack and challenge the changing justifications for disqualifying gay people from military service. In the late nineteenth and early twentieth centuries, the rationales were always centered on the gay soldiers themselves: they were said to be security risks, mentally unstable,$^{12}$ cowardly, ${ }^{13}$ and lacking in discipline.$^{14}$ Over time, however, these rationales started to erode. This change was inevitable as highly decorated, clearly effective soldiers came out or were exposed as gay or lesbian. ${ }^{15}$ The many

12. Melissa Wells-Petry, Exclusion: Homosexuals and The Right to Serve 113-18 (1993). According to Akhil Amar and Alan Hirsch, the official policy against gays in the military resulted largely from "historical accident":

Many soldiers returned from World War I suffering from shell shock. The emerging psychiatric profession offered to help the government minimize such problems in the future by screening soldiers to keep out the mentally ill or poorly adjusted. At the time, homosexuality was regarded as a mental illness, so the screening policy kept identified homosexuals out of the armed forces.

AkHil Reed amar \& Alan Hirsch, for the People: What the Constitution REALLY SAYS ABOUT YOUR RIGHTS 141 (1998).

13. Randy ShILTS, Conduct Unbecoming: Gays and Lesbians in the U.S. MILITARY 15 (1993) (quoting psychiatrist Albert Abrams, who wrote in his 1918 essay, "Homosexuality - A Military Menace," that "the homosexualist is not only dangerous, but an ineffective fighter").

14. WELLS-PETRY, supra note 12, at 118-19; Diane H. Mazur, The Unknown Soldier: A Critique of "Gays in the Military" Scholarship and Litigation, 29 U.C. DAVIS L. REV. 223, 234 (1996).

15. See, e.g., Cammermeyer v. Perry, 97 F.3d 1235, 1236 (9th Cir. 1996) (concerning "a highly decorated nurse" who received the Bronze Star for distinguished service in Vietnam but who was discharged because she was a lesbian); Steffan v. Aspin, 8 F.3d 57, 59 (D.C. Cir. 1993) (concerning "an exceptional midshipman" who earned "the respect and praise of his superior officers" and for whom "the sky was the limit" who was discharged from the Naval Academy two weeks before graduation because he disclosed his homosexuality to a classmate); Watkins v. United States Army, 875 F.2d 699, 701 (9th Cir. 1989) (en banc) (concerning an openly gay man described as "an outstanding soldier" and repeatedly promoted during his twelve years of service during and after Vietnam conflict; when Watkins sued to prevent his discharge, the court ruled that the Army could not discharge Watkins on the basis of his sexual orientation because it was disclosed at the time Watkins was drafted); see also SHILTS, supra note 13 (describing the history of gay men and lesbians in the U.S. military and the occasional "purges" that would result in the exposure and termination of many gay and lesbian soldiers). 
promotions and glowing reviews these soldiers received during their service showed that they had discipline and courage. ${ }^{16}$ The almost universal opinion within the psychiatric community that homosexuality is not a mental illness ${ }^{17}$ made it untenable for the military to argue that gay people were inherently less stable than any other group. The illogic of the ban started to become clear as gay rights advocates pointed out that emotional problems and security breaches were more likely to occur if soldiers were forced to hide their sexual orientation; lifting the ban would mitigate rather than aggravate these risks.

Nonetheless, when President Bill Clinton proposed to lift the ban upon taking office in early 1993, Congress balked. Ultimately, the compromise DADT policy emerged - a policy which, in theory, forbids military officials from asking whether soldiers are gay or lesbian, but also forbids gay and lesbian soldiers to be open about their orientation. ${ }^{18}$ While this policy may have many flaws, ${ }^{19}$ the

16. See MARy ANN Humphrey, My COUNTRY, My Right to SERVE: EXPERIENCES OF GAY MEN AND WOMEN IN THE MILITARY, WORLD WAR II TO THE PRESENT (1990).

17. AM. PSYChIATRIC ASS'N, DIAGNOSTIC AND STATISTICAL MANUAL OF MENTAL Disorders 261-83, 380 (3d ed. 1980); SHILTS, supra note 13, at 715; Am. Med. Ass'n, Health Care Needs of the Homosexual Population, at http:/www.ama-assn.org/apps/pf_new/pf online?f_n=browse\&doc=policyfiles/HnE/H-160.991.htm (last visited Oct. 16, 2004) (calling for a "physician's nonjudgmental recognition of sexual orientation" and instructing physicians to "oppose[ ] ... therapy that is based upon the assumption that homosexuality per se is a mental disorder").

18. 10 U.S.C. $\$ 654$ (b)(1) (1994). The statute provides in pertinent part:

(b) Policy. - A member of the armed forces shall be separated from the armed forces under regulations prescribed by the Secretary of Defense if one or more of the following findings is made...

(1) That the member has engaged in, attempted to engage in, or solicited another to engage in a homosexual act or acts...

(2) That the member has stated that he or she is homosexual or bisexual...

(3) That the member has married or attempted to marry a person known to be of the same biological sex.

The "don't ask" portion of the policy is contained in a regulation which states that "[a]pplicants for enlistment, appointment, or induction shall not be asked or required to reveal whether they are heterosexual, homosexual, or bisexual." Dep't of Def. Directive No. 1304.26, encl. 1, II E 1.2.8.1 (Dec. 21, 1993). See also Dep't of Def. Directive Nos. 1332.30 \& 1332.14 (applying "don't ask" policy to officers and enlisted service members, respectively, in the course of their service). Thus, while the "don't tell" part of the policy is enshrined in statute, the "don't ask" portion is "strictly a regulatory creation." Kenji Yoshino, Assimilationist Bias in Equal Protection: The Visibility Presumption and the Case of "Don't Ask, Don't Tell", 108 YALE L.J. 485, 539 (1998).

19. Not the least of these flaws is the fact that discharges due to homosexuality have accelerated rather than slowed since its inception. See Philip Shenon, Pentagon Moving to End Abuses of 'Don't Ask, Don't Tell' Policy, N.Y. TIMES, Aug. 13, 1999, at A1 (noting that $67 \%$ more gay and lesbian troops were discharged in 1997 - a total of 997 individuals than were discharged in 1994, the first full year the DADT policy was in effect). More recent drops in discharges are due to America's temporary involvement in war rather than any permanent shift in the practical effects of the policy. See John Files, Study Says Discharges 
Congressional debates leading to its implementation achieved something valuable: they showed that some rationales for the ban on gays in the military seem to be off the table. Security risks, cowardice, and mental illness of gay people have, for the most part, lost respectability in this debate.

The argument shifted. The new mantra became "unit cohesion." Indeed, when gay and lesbian service members have challenged the DADT policy, the government has defended not by raising any of the old justifications for the homosexual exclusion policy, but by resting upon "unit cohesion," protecting "the privacy of heterosexuals," and reducing "sexual tension." 20

If we unpack "unit cohesion," however, we see that the point of concern has actually shifted; the anticipated source of rule violations, breakdown in discipline, and insubordination has changed. The problem, it turns out, is not so much the gay soldier himself, but the reaction he is likely to elicit in others: their fear of the "gay gaze," their feelings of invaded privacy, their hostility. Put more pointedly, the fear is not so much that openly gay soldiers will violate military rules or underperform, but rather that one soldier's open homosexuality will cause another soldier to fall short in executing his duties. ${ }^{21}$

Interestingly, the "unit cohesion" argument thus works in precisely the opposite direction from "diversity" rationales for affirmative action in higher education. In the educational context, the argument is that everyone will learn more, and more effectively, if the students bring to the enterprise a diverse array of experiences, some of which may flow from their personal characteristics, such as gender, race, age,

Continue Under 'Don't Ask, Don't Tell', N.Y. TimES, Mar. 24, 2004, at A18 (suggesting that America's involvement in war may counteract the otherwise steady increase in discharges of homosexuals, and noting that 787 were discharged in 2003, "the lowest number since 1995," compared with 906 in 2002 and 1,273 in 2001); Beth Fouhy, Soldier Dismissed After Revealing He's Gay, FindLaw, at http://news.findlaw.com/ap_stories/a/w/1152/6-21-2004/2004 0621051504_40.html (June 21, 2004) (noting that 770 people were discharged for homosexuality in 2003 , a reduction from 1,227 discharges in 2001, "before the invasions of Afghanistan and Iraq").

20. See, e.g., Able v. United States, 968 F. Supp. 850, 858 (E.D.N.Y. 1997), rev'd on other grounds, 155 F.3d 628 (2d Cir. 1998) ("The government does not justify its discrimination by reference to some defect in the performance of homosexuals, or claim that they represent a security risk as likely targets for blackmail," but instead "says that the Act helps foster unit cohesion, promotes the privacy of heterosexuals, and reduces sexual tensions.")

21. Judge Eugene Nickerson came straight to the point in describing this rationale: "[T] he known presence of homosexuals may disrupt the unit because heterosexual members may morally disapprove of homosexuals. This is an outright confession that 'unit cohesion' is a euphemism for catering to the prejudices of heterosexuals." Id. See also Yoshino, supra note 18, at 553 (“' $T$ The justifications for 'don't ask, don't tell' - unit cohesion, privacy, and sexual tension - primarily focus not on the gay servicemember but on the straight servicemember. This can be counted as a pro-gay achievement, as it correctly traces the source of the dysfunction not to the gay servicemember, but to the straight service member." (internal footnote omitted)). 
and religion (just to name a few). ${ }^{22}$ In the military context, on the other hand, the fear seems to be that some forms of diversity will prove so challenging, so distracting, that soldiers' ability to learn and perform will be compromised.

Military officials faced a similar dynamic when they proposed racial integration of the armed forces. Military commanders believed that white and black soldiers could not live and work together; morale, discipline, and unit cohesion would suffer. Notwithstanding these fears, officials determined that wholesale integration was necessary. Many contend that this integration has been a success, proving that prejudice and fear can be overcome when soldiers subject themselves to the discipline demanded by military life. ${ }^{23}$ While some critics have argued that the military should follow the same path in integrating the armed forces with respect to race and sexual orientation, Congressional repeal of DADT in the short term is unlikely. Therefore, this Essay proposes a more incremental approach, one that does not launch a direct, normative attack on DADT, but instead attempts to demonstrate that the policy rests upon fears that are baseless - even in a military setting. Stage I calls for changes that could be implemented by executive order, without Congressional action.

If, as Judge Eugene Nickerson has asserted, "the only conceivable way that the presence of known homosexuals could undermine the cohesion of the unit is 'by the negative reactions of service members who disapprove of homosexuality," 24 military officials should consider instituting policies that seek out and nurture heterosexual soldiers who are tolerant of homosexuality. Our proposal does just this by allowing the perpetrators and victims of discrimination to voluntarily separate themselves into two distinct groups.

As a purely descriptive matter, our screening mechanism is likely to have two channeling functions that would be mutually reenforcing. First, gay soldiers would likely opt for the inclusive command. While gay and lesbian soldiers could also opt for an exclusive command, ${ }^{25}$ the

22. See, e.g., Grutter v. Bollinger, 539 U.S. 306 (2003) (characterizing a diverse university student body is a compelling state interest, and observing that diversity creates substantial educational benefits); Regents of the Univ. of Cal. v. Bakke, 438 U.S. 265 (1978).

23. See Charles C. Moskos \& John Sibley Butler, All That We Can Be: BlaCK LEADERSHIP AND RACIAL INTEGRATION THE ARMY WAY (1996) (suggesting the military has become the most race-egalitarian institution in American society).

24. Able, 968 F. Supp. at 859 (quoting Philips v. Perry, 106 F. 3d 1420, 1435 (9th Cir. 1997)).

25. Closeted gay individuals often find other gays or gay allies threatening, if for different reasons than intolerant individuals find them threatening. See BYRNE FONE, HOMOPHOBIA: A HISTORY 6 (2000) ("Homophobia is not limited to heterosexuals, of course. It can also be found among ... repressed homosexuals."). This might stem from a fundamental fear of being outed, either within the military, or within their personal lives, and will cause some gay soldiers to opt for the exclusive command. 
screening mechanism would probably reduce their incentives to do so. ${ }^{26}$ After all, fellow soldiers in the exclusive command are there because they've expressed a preference not to serve with any gay people.

Second, intolerant heterosexual soldiers are likely to opt for the exclusive command. Intolerant soldiers - taking into account the channeling effect on gay soldiers - can reduce their expected contact with gay soldiers by opting for the exclusive command. And intolerant soldiers are also likely to be less willing to ambiguate their own sexuality by expressing even minimal support for gay rights.

The remaining individuals - those who don't fall into either of these two categories - might be classified as tolerant heterosexuals. They are neither gay (who we expect, overall, will choose the inclusive command), nor facially intolerant toward gays (who we expect will choose the exclusive command). As we discuss in depth later, the choice made by these individuals is more complex, and may depend in part on the magnitude of the two channeling effects. Tolerant soldiers will be less likely to choose the exclusive command if it is a small, stigmatized group. But they will also be less likely to join the inclusive command if it is small enough to potentially mark them as gay.

This Essay's argument unfolds in three steps. Section II will explain how the inclusive command would deliver the benefits of amelioration, demonstration, and realignment. Section III will put our proposal in context by presenting a brief history of exclusion and integration in the U.S. military, with a focus on women and racial minorities. In this section we will also consider briefly the racial integration of schools. Our contention will be that strategies of segregated inclusion and voluntary integration have facilitated transition to subsequent, mandatory integration, and that analogous strategies might be effective as gay men and lesbians take their turn at full integration in the military.

Section IV will describe the inclusive command approach to integrating sexual minorities into the military, and examine several problems related to implementation. In conclusion, we will argue that

26. Indeed, we perversely considered returning to the rule of total exclusion with regard to the exclusive command as a way of further bolstering the tendency of gays to choose the inclusive command. Under this alternative, the military was able to "ask" and then remove gay and lesbian soldiers from the exclusive command. Soldiers who are on the fence would arguably feel less comfortable opting into such a system, and thus choose the inclusive command. In equilibrium, most gay soldiers would be better off than the current regime because they would be able to opt for a safer environment, the inclusive command, and a greater number of soldiers overall may participate. But in the end, we reject this idea. The idea of retrenchment to total exclusion, even if limited to the exclusive command, is too unpalatable to be proposed. But see JANET E. HALLEY, DON'T: A READER's GuIDE TO THE MILITARY'S ANTI-GAY POLICY 1 (1999) (noting that "don't ask, don't tell" is "much, much worse than" total exclusion since it achieves essentially the same ends, but in a way which is less offensive and less easily contestable). 
we must not allow the "don't ask, don't tell" policy to set the parameters for gay participation in the U.S. military. Given the continuing centrality of military service in many conceptions of full citizenship, as well as the substantial material benefits that accompany service in the armed forces, this issue deserves all of the energy we can muster to jump-start the debate. We must find new ways to integrate openly gay people into military life.

\section{The BenEFITS OF SELF-SEgREgation}

The tendency of self-segregation by intolerant heterosexuals into the exclusive command and by tolerant heterosexuals and gay and lesbian soldiers into the inclusive command will produce three distinct types of benefits: amelioration (of current discrimination), demonstration (that the unit cohesion rationale does not require the exclusion or closeting of gay and lesbian soldiers), and realignment of political allies and enemies (creating a common cause for pro-gay legislators on the left and pro-defense legislators on the right).

\begin{tabular}{|l|l|l|}
\hline TABLE 1: EVOLVING EFFECTS OF THE INCLUSIVE COMMAND \\
\hline TYPE OF EFFECT & STAGE I & STAGE II \\
\hline AMELIORATION & $\begin{array}{l}\text { More supportive } \\
\text { environment } \\
\text { Reduced chance of } \\
\text { harassment, abuse, } \\
\text { outing, or witch hunts }\end{array}$ & $\begin{array}{l}\text { Speech and conduct } \\
\text { discrimination } \\
\text { eliminated } \\
\text { Safe haven for gays in } \\
\text { exclusive unit if outed } \\
\text { or come out }\end{array}$ \\
\hline DEMONSTRATION & $\begin{array}{l}\text { Testing number of } \\
\text { soldiers willing to serve } \\
\text { with gay people } \\
\text { Testing relative } \\
\text { performance of } \\
\text { inclusive and exclusive } \\
\text { commands }\end{array}$ & $\begin{array}{l}\text { Testing whether } \\
\text { heterosexual and } \\
\text { openly gay soldiers can } \\
\text { work together } \\
\text { effectively } \\
\text { Testing whether } \\
\text { openly gay soldiers are } \\
\text { more likely to violate } \\
\text { military code }\end{array}$ \\
\hline REALIGNMENT & $\begin{array}{l}\text { Attract supporters of individual choice } \\
\text { Attract supporters of unit cohesion } \\
\text { Attract supporters of strong defense and boost } \\
\text { recruitment }\end{array}$ \\
\hline
\end{tabular}


At first blush, the inclusive command concept might appear to aggravate rather than ameliorate discrimination in the military on the basis of sexual orientation. One of the clear consequences of the proposal is to create "safe" spaces, but those spaces protect both those who support and those who oppose the inclusion of gay men and lesbians in the military. The exclusive command, by insulating some soldiers from openly gay and lesbian fellow soldiers, might be seen as legitimizing the desire for such insulation. Granted, to the extent the inclusive command rests upon a system of "separate but equal" classifications, it will strike many readers as distasteful, and even quite harmful. ${ }^{27}$ Certainly, compared to a world in which gay and lesbian citizens are freely admitted into the service without restrictions peculiar to their sexual orientation, the inclusive command is not attractive. But if we take as our starting point the world we actually occupy, where the DADT policy constrains gay peoples' speech and conduct, heterosexuals are never given the opportunity to show that they are capable of working effectively with openly gay soldiers, and gay people are regularly discharged from the service because of their sexual orientation, the inclusive command gains important ground, if only as a set of temporary strategies. At the very least, the inclusive command increases the options available to gay and heterosexual soldiers, and thus improves their situations.

The inclusive command would ameliorate the discriminatory character of the DADT policy in the day-to-day lives of gay soldiers. In stage I, the inclusive command would ease the lives of gay and lesbian soldiers by allowing them to work in units filled with fellow soldiers who have suggested that they are not prejudiced with respect to sexual orientation. In the inclusive unit, this reduction in prejudice would presumably lead to a drop in homophobic jokes and comments, harassment on the basis of sexual orientation, and other anti-gay behavior. ${ }^{28}$ These benefits would be felt immediately, because it would

27. Some readers might even wonder if it is constitutional. The answer is almost certainly yes. The constitutionality of the current "don't ask, don't tell" policy has been bitterly debated but generally upheld. See Able v. United States, 88 F.3d 1280 (2d Cir. 1996), remanded to 968 F. Supp. 850 (E.D.N.Y. 1997), rev'd, 155 F. 3d 628 (2d Cir. 1998); Richenberg v. Perry, 97 F.3d 256 (8th Cir. 1996); Holmes v. Cal. Army Nat'l Guard, 124 F.3d 1126 (9th Cir. 1997). Our proposal is less burdensome on gay, lesbian, and bisexual service members than that policy. Moreover, in a constitutional system that reviews classifications based on sexual orientation under the most easily satisfied "rational basis" test, the military should be able to show that the system is rationally related to a legitimate governmental purpose. Indeed, courts have traditionally shown great deference to military decision making, given the national security interests involved.

28. In theory, this atmosphere should currently exist in the military. In the Navy, for example, the personnel chief, Vice Admiral Daniel T. Oliver, issued a memorandum on October 28, 1999 reminding commanding officers that they "must not condone homosexual jokes, epithets or derogatory comments, and must ensure a command climate that fosters respect for all individuals." Elizabeth Becker \& Katherine Q. Seelye, The Military Orders Spot Check of Bases on Gay Harassment, N.Y. TimES, Dec. 14, 1999, at A1. Yet these 
not be necessary for gay and lesbian service members to be out of the closet in order to appreciate a more supportive environment. Simply knowing that their fellow service members are tolerant of homosexuality could ease the strain of DADT. Heterosexual service members in the stage I inclusive commands, as well, would feel some amelioration of the harassment and discrimination they can suffer if they express support for gay rights under the current regime. Even in stage I, while DADT still applies, the inclusive command would ameliorate discrimination by creating a space in which gay and nongay service members could safely and openly express their support for gay rights.

In stage II, the inclusive command would ameliorate discrimination even more dramatically. Because the DADT policy would no longer apply to inclusive commands at this stage, gay and lesbian soldiers would be permitted to be open about their orientation. The stage II inclusive command would alleviate the stress of secrecy that so many gay and lesbian soldiers must bear. It would give gay and lesbian soldiers the same rights of free speech enjoyed by heterosexual soldiers. ${ }^{29}$ Gay and lesbian service members who opt for the exclusive units could also benefit. Although DADT would continue to apply in exclusive commands, the consequences of that policy could be changed in time of transition. Closeted soldiers in the exclusive command whose sexual orientation became public (through their own decision to reveal it or because of others' investigations) could avoid discharge by transferring to an inclusive command.

The inclusive command would also have evolving demonstration effects. In stage I, the inclusive command would demonstrate, if nothing else, the extent to which new recruits support gay rights. The first question directly solicits recruits' preferences about serving with

policies are clearly not effective and the military knows it. A survey of service members conducted by the Department of Defense in 1999 revealed that $80 \%$ of soldiers had "heard offensive speech, derogatory names, jokes, or remarks about homosexuals in the last 12 months," $85 \%$ "believed such comments were tolerated to some extent," and $37 \%$ said they had "witnessed or experienced an event or behavior toward a Service member that they considered to be harassment based on perceived homosexuality." OFFICE OF THE INSPECTOR GEN., DEP'T OF DEF., REPORT ON THE MILITARY ENVIRONMENT WITH RESPECT TO THE HOMOSEXUAL CONDUCT POLICY, at i-ii (2000). See also Francis X. Clines, Killer's Trial Shows Gay Soldier's Anguish, N.Y. TIMES, Dec. 9, 1999, at A18 (noting the "months of vile name calling, rumor mongering," "harassment," and "taunting" that preceded the beating to death of Pfc. Barry Winchell "with a baseball bat as he slept in his barracks bed").

29. See Tobias Barrington Wolff, Compelled Affirmations, Free Speech, and the U.S. Military's Don't Ask Don't Tell Policy, 63 BROOK. L. REV. 1141 (1997) (noting that DADT implicitly requires gay and lesbian soldiers, even when silent as to their sexual orientation, falsely to affirm assumptions that they are heterosexual). 
gay soldiers. Because this question is confidential and unrelated to the respondent's assignment or career path, it provides powerful information into whether DADT is necessary as a recruitment device..$^{30}$

Moreover, the second question facilitates a limited test of the unit cohesion hypothesis itself. The self-segregating of people based upon attitudes toward homosexuality would allow military commanders to measure and compare the performance of these two distinct groups of people. Under some versions of the "unit cohesion" theory, one might expect soldiers in the exclusive command to work more effectively (because they were less likely to have to interact with gay colleagues). But this prediction can be tested. We might find that the service members who selected the inclusive unit work more effectively with people who are different from them in multiple ways than do those who express unwillingness to serve with homosexuals. Or it is possible that both groups would perform better when segregated than they do when mixed together under the current system. These are empirical questions that are impossible to answer a priori. But even while DADT still applies in stage $I$, the inclusive command creates a structure for gathering data and comparing the performance of people with distinctly different attitudes toward homosexuality. ${ }^{31}$

In the second stage, when gay and lesbian members of the inclusive command are permitted to be open about their orientation, a broader test of the unit cohesion theory is possible. It would then be possible to test whether heterosexual soldiers are rendered somehow less effective by the "gay gaze" - that is, when they work along side openly gay colleagues. ${ }^{32}$

30. Recent data suggest that it is not, as people in the 18- to 29-year-old age group show increasing levels of acceptance for homosexuality. See infra note 90 and accompanying text.

31. During stage II, it will become possible for commanders to identify a greater number of service members as gay, lesbian, or bisexual. This in turn will permit some comparison, as performance levels of gay, lesbian, and bisexual service members are measured against nongay members. This could be a positive development, as long as gay service members are held to the same standards as nongay members. See Yoshino, supra note 18, at 544 (noting the way DADT prevents gay and lesbian service members from disproving the assumption that openly gay personnel cannot serve effectively).

32. In theory, it should be possible to test this even now. In some military settings, gay, lesbian, or bisexual service members have been permitted to serve even after commanders and fellow service members become aware of their homosexuality. Commanders of such units could test the unit cohesion hypothesis by tracking performance levels before and after the date on which the service member's homosexuality became widely known. While theoretically possible, such studies are unlikely to occur because a commander might violate DADT if he or she fails to initiate discharge proceedings against an openly gay service member. Thus the commander's self interest precludes an admission that the gay service member's homosexuality is or was widely known within the unit. 
Gay and lesbian soldiers have already demonstrated that the early rationales for exclusion - emotional instability, security risks, and ineffectiveness - were without merit. But these men and women could only show that closeted gays could serve effectively. Never have we created an environment in which openly gay people could prove their abilities without fear of official reprisal. ${ }^{33}$ The inclusive command takes us that additional step. And it takes us there not by creating a segregated unit just for gays ${ }^{34}$ (as the United States has at times maintained for African-American and Japanese-American soldiers), for this would prove only that gays could serve in units reserved for gays. An exclusively gay command would fail to address the unit cohesion problem head-on. Only a regime that places gay and non-gay soldiers together - bunk-to-bunk, shoulder-to-shoulder, showerhead-toshowerhead - can prove that openly gay people can serve and (perhaps more importantly) that heterosexual people can serve with them.

The final effect of the inclusive command would be a realignment of political interests. By allowing gay people to serve without forcing uncomfortable heterosexual people to serve with them, the inclusive command structure could create a common cause for gay rights advocates on the left and various groups of conservative legislators on the right. This effect would be particularly pronounced in stage I, when DADT remains in place for both types of commands. Indeed, during stage I, the inclusive command proposal appears to be Pareto superior to the current DADT system, as every relevant participant's position improves. By channeling gay and lesbian soldiers toward the inclusive command, the sorting mechanism employed in stage I would

33. This may be an overstatement with respect to individuals. Anecdotal evidence suggests that some openly gay service members have been permitted to serve and have even received promotions. Their success seems to turn on the tolerance of commanders and extent to which circumstances create a demand for their presence. See, e.g., Nathaniel Frank, Gays and Lesbians at War: Military Service in Iraq and Afghanistan under "Don't Ask, Don't Tell," Working Paper, Center for the Study of Sexual Minorities in the Military, University of California, Santa Barbara (September 15, 2004), available at http:/www. gaymilitary.ucsb.edu/Publications/Frank091504_GaysAtWar.doc (noting that sexual minorities serve on the front lines of Operation Enduring Freedom and Operation Iraqi Freedom, taking combat and combat-support roles as officers and enlisted personnel in the Army, Air Force, Navy, and Marines, and that despite DADT, many serve openly or are known to a majority of the troops in their unit); HUMPHREY, supra note 16, at 248-57 (noting an openly gay man who served and received promotions during Vietnam war). Unfortunately, most of the evidence of service by openly gay personnel tends to be anecdotal. The military cannot acknowledge the extent to which commanders tolerate and even support the continued service of openly gay members, since such commanders are technically violating DADT.

34. This was proposed by Miriam Ben-Shalom at the beginning of the crisis in the Persian Gulf. She wrote to President George H.W. Bush suggesting the formation of a "gay command" consisting of current and former service members who were gay or lesbian. She pointed out that the government could save thousands in training costs by deploying these soldiers, who were ready and willing to serve. See SHILTS, supra note 13, at 727. 
give homophobic service members a greater sense of insulation from homosexuality in the exclusive command. Finally, stage I should also dominate DADT in the minds of the military commanders who are morally neutral on homosexuality but fear, in a purely instrumental way, the effect integration will have on unit cohesion. Allowing people to sort according to their attitudes toward homosexuality could actually boost unit cohesion in both the inclusive and the exclusive commands. Indeed, it seems the only people who would not be made better off by the move to inclusive commands would be people who do not like gay people and derive enjoyment from harassing and harming them. It would be surprising to hear any legislator argue publicly that the interests of such people must be included in the calculus.

A less positive way to describe the realignment effect is that an inclusive command might create a wedge in traditional anti-gay coalitions, giving legislators who are generally unsympathetic to gay rights a reason to defect from their usual political alignment. For example, a conservative law maker might tell her constituents that the inclusive command will more fairly distribute the burdens and dangers of military service, requiring gay and lesbian as well as heterosexual citizens to show their patriotism. ${ }^{35}$ Particularly when the military has great need for soldiers (such as when the country is waging an unpopular war, or a strong peacetime economy makes it more difficult to find talented recruits; or, as is arguably the case in 2004, multiple commitments around the globe are taxing some branches of the military to capacity ${ }^{36}$ ), conservative legislators might see greater appeal in a policy that finds a way to include gay citizens in the military ${ }^{37}$ Indeed, between 1999 and 2004, DADT caused the armed forces to discharge nearly 1,000 service members who possessed special skills needed in Iraq; an inclusive command might have provided a way to retain those members. ${ }^{38}$ The fact that the exclusive command offers some soldiers a way to decrease their probability of

35. See Akhil Reed Amar, Second Thoughts: What the Right to Bear Arms Really Means, THE New RePUblic, July 12, 1999, at 24. Professor Amar argues for universal, "compulsory or quasi-compulsory national service, with both military and nonmilitary alternatives." Id. at 26.

36. See Eric Schmitt, Other Services Eyed by Army for Recruiting, N.Y. TIMES, July 9, 2004, at A1.

37. See Nathaniel Frank, Why We Need Gays in the Military, N.Y. TIMES, Nov. 28, 2003, at A43 (eliminating the ban on openly gay service members would promote national security and military readiness).

38. See Press Release, Ctr. for the Study of Sexual Minorities in the Military, Univ. of Cal., Santa Barbara, Mission-Critical Specialists Discharged For Homosexuality: New Data Reveal Extensive Talent Loss Under Don't Ask, Don't Tell (June 21, 2004), at http://www. gaymilitary.ucsb.edu/PressCenter/press_rel_2004_0621.htm. 
serving with gays only adds to the appeal for socially conservative legislators. At the very least, the inclusive command could give conservative legislators who support a strong national defense a way to trade off the benefits of a potentially larger, stronger military against the "moral values" that would otherwise lead them to oppose any expansion in gay rights.

Initially, one might suspect that liberals would be against an inclusive command because it doesn't go far enough in eliminating DADT, while implicitly condoning and legitimizing anti-gay sentiment by making it the basis for a new exclusive command. However, when framed as part of a broader goal (the move from stage I, to stage II, to full integration) liberals should accept the program, if only as necessary data gathering to support their position. ${ }^{39}$

\section{HistoricAl PARALLELS}

The foregoing arguments for incremental progress are likely to be offensive to readers impatient for a simple regime of nondiscrimination. We share this impatience. But it is useful to remember that neither racial integration of our schools nor of the military occurred in one fell swoop. Instead, various intermediate forms of (admittedly discriminatory) inclusion were important precursors to the ultimate mandate of integration. This section reminds us of these histories to make more plausible the idea that intermediate steps of the kind suggested in our proposal might be a necessary evil.

The history of racial integration of public education might, in stylized fashion, be broken into four core stages: exclusion, segregated inclusion, voluntary integration, and mandatory integration. In the exclusion stage, African-American children in the United States were at first denied the right to education. The country then moved to a system of segregated inclusion, the sort of "separate but equal" regime found constitutional in Plessy $v$. Furgeson. ${ }^{40}$ African-American children were permitted to go to school, but only to schools designated specifically for them. White children continued to attend schools that were exclusively white.

39. Indeed, Rep. Barney Frank (D-Mass.) heard Jennifer describe the idea at a conference and was so taken with it that he asked for a written description. Frank seems to be a great believer in pragmatic incrementalism, though, so perhaps he would take to the idea more easily than the average liberal politician.

40. 163 U.S. 537 (1896). 


\begin{tabular}{|c|c|c|c|}
\hline CORE STAGE & $\begin{array}{l}\text { RACE IN } \\
\text { EDUCATION }\end{array}$ & $\begin{array}{l}\text { RACE IN } \\
\text { MILITARY }\end{array}$ & $\begin{array}{l}\text { SEXUAL } \\
\text { ORIENTATION } \\
\text { IN MILITARY }\end{array}$ \\
\hline EXCLUSION & $\begin{array}{l}\text { African- } \\
\text { American } \\
\text { children denied } \\
\text { right to } \\
\text { education }\end{array}$ & $\begin{array}{l}\text { African- } \\
\text { Americans } \\
\text { denied the } \\
\text { right to serve }\end{array}$ & $\begin{array}{l}\text { Homosexual } \\
\text { exclusion policy }\end{array}$ \\
\hline $\begin{array}{l}\text { SEGREGATED } \\
\text { INCLUSION }\end{array}$ & $\begin{array}{l}\text { "Separate but } \\
\text { equal" schools }\end{array}$ & $\begin{array}{l}\text { Segregated } \\
\text { units }\end{array}$ & Never used \\
\hline $\begin{array}{l}\text { VOLUNTARY } \\
\text { INTEGRATION }\end{array}$ & $\begin{array}{l}\text { "Freedom of } \\
\text { choice" } \\
\text { Whites have } \\
\text { option of } \\
\text { busing to black } \\
\text { schools } \\
\text { White suburbs } \\
\text { have option of } \\
\text { accepting black } \\
\text { students from } \\
\text { urban areas }\end{array}$ & Never used & $\begin{array}{l}\text { Proposed } \\
\text { inclusive } \\
\text { commands }\end{array}$ \\
\hline $\begin{array}{l}\text { MANDATORY } \\
\text { INTEGRATION }\end{array}$ & $\begin{array}{l}\text { Nominal } \\
\text { holding of } \\
\text { Brown v. Board } \\
\text { of Education }\end{array}$ & $\begin{array}{l}\text { Integration } \\
\text { order by } \\
\text { Truman }\end{array}$ & Long-range goal \\
\hline
\end{tabular}

The crucial phase in any process of integration, well illustrated in the educational context, is mandatory integration. The U.S. Supreme Court's holdings in Brown v. Board of Education, ${ }^{41}$ followed by the remedial cases in which integration plans were approved and imposed "with all deliberate speed," 42 represent this mandatory stage. The Court's nominal holding in Brown v. Board of Education ${ }^{43}$ was to reject Plessy's segregated education system. In most cases, Brown was followed by either continued segregation or by various attempts to desegregate through voluntary action. Voluntary integration strategies have provided opportunities, in some areas, for school districts and the families within them to integrate proactively, through their own

41. 349 U.S. 294 (1955).

42. Brown, 349 U.S. at 301. For examples of such remedial plans, see Swann $v$. Charlotte-Mecklenburg Bd. of Educ., 402 U.S. 1 (1971); Milliken v. Bradley, 418 U.S. 717 (1974).

43. 347 U.S. 483 (1954). 
exercise of choice; these choices were made in the shadow of a mandatory norm.

This Essay proposes an inclusive command strategy as an alternative to sweeping judicial reform analogous to Brown. This raises an important empirical question as to whether voluntary integration can succeed without a Brown-like Supreme Court ruling. It may be that other important actors, such as Congress (by virtue of amending the DADT policy, at least with respect to the inclusive command) or important military figures (such as $\mathrm{H}$. Norman Schwartzkopf or Colin Powell, expressing support for the inclusive command) could similarly shift the background norms toward integration of sexual minorities. ${ }^{44}$

Although most school districts skipped the voluntary integration stage, we can find some examples of it. It is important to acknowledge that voluntary integration almost always followed, rather than preceded, the articulation of an overarching norm of desegregation. To have any chance of success, voluntary integration strategies may require a prior statement, such as that in Brown, making clear that norms have changed. In practice, voluntary systems have been used to "ease in" the application of a court-imposed desegregation order. In theory, however, voluntary systems could precede the articulation of a mandatory norm. In the shadow of Brown, some localities adopted socalled "freedom of choice" plans, which gave white and black families the option of participating in the integration of the schools. Because it was understood that white students would not opt to attend predominantly black schools and black students would be intimidated and pressured not to attend predominantly white schools, the "freedom of choice" plans were used by Southern school districts as a tool of resistance to court-imposed integration orders..$^{45}$ Although the U.S. Supreme Court eventually struck down "freedom of choice" plans when other methods, such as rezoning, could more quickly achieve the ends of desegregation, the Court suggested that the concept could - at least in theory - be used to integrate schools fairly. ${ }^{46}$

44. Such "norm entrepreneurs" can have dramatic effects on shared understandings of social meaning. See Cass R. Sunstein, Social Norms and Social Roles, 96 Colum. L. REv. 903, 929 (1996) (discussing how "norm entrepreneurs" can affect public discourse and, therefore, the shape of social norms).

45. $C f$. CONSTANCE CuRRY, Silver Rights: THE STORY OF THE CARTER FAMILY'S BRaVe Decision to SEND THEIR CHILDREN to AN All-White SCHOOl AND Claim THEIR CIVIL RIGHTS 29 (1995) (recounting the oral history of an African-American family who took advantage of "freedom of choice" policy and sent seven school-age children to a formerly all-white school, despite intense harassment and intimidation).

46. See Green v. County Sch. Bd., 391 U.S. 430 (1968) (striking down a "freedom of choice" plan when three years after implementation no white child had chosen to go to the formerly black school, and $85 \%$ of county's black students remained in that school). Regarding such plans generally, the Court stated, "If the means prove effective, it is 
Volunteerism is still alive and well today as a dominant tool of desegregation. Several desegregation plans ask whether suburban school districts would volunteer to accept students who would be bused out from predominantly black urban districts. ${ }^{47}$ A strategy employing elements of volunteerism can be found in ever-popular magnet schools. Majority and minority families have the option of registering for such schools, and school districts attempt to lure a racially mixed group of students to these schools by offering special programs and resources there. Instead of mandated busing, the preference is for voluntary integration.

The history of racial (and sexual ${ }^{48}$ integration of the military is also partially analogous. As before, we did not move simply from a regime of exclusion to one of mandatory integration. As in the educational context, African-Americans were officially excluded from service at various points in our nation's history. ${ }^{49}$

acceptable, but if it fails to undo segregation, other means must be used to achieve this end." Id. at 440 (citation omitted). See also Vaughns v. Bd. of Educ., 627 F. Supp. 837 (D. Md. 1985) (Prince George's County); Bronson v. Bd. of Educ., 604 F. Supp. 68, 75 (S.D. Ohio 1984) (Cincinnati); Clark v. Bd. of Educ., 705 F.2d 265, 272 (8th Cir. 1983) (Little Rock); United States v. Bd. of Educ., 554 F. Supp. 912, 917, 924-26 (N.D. Ill. 1983) (Chicago); Flax v. Potts, 567 F. Supp. 859, 874 (N.D. Tex. 1983) (Fort Worth); United States v. Texas Educ. Agency, 679 F.2d 1104, 1110 (5th Cir. 1982) (Port Arthur); Arthur v. Nyquist, 514 F. Supp. 1133, 1139 (W.D.N.Y. 1981) (Buffalo); Smiley v. Vollert, 453 F. Supp. 463, 476 (S.D. Tex. 1978) (Galveston), modified sub nom., Smiley v. Blevins, 514 F. Supp. 1248, 1263 (S.D. Tex. 1981).

47. An en banc Eighth Circuit Court of Appeals approved a consent decree containing an interdistrict transfer provision in the St. Louis metropolitan area. Liddell v. Missouri, 731 F.2d 1294 (8th Cir. 1984), cert. denied, 469 U.S. 816 (1984). Other courts have commented generally on the advantages of interdistrict transfer arrangements as something states and suburbs might undertake voluntarily. See, e.g., Columbus Bd. of Educ. v. Penick, 443 U.S. 449, 488 (1979) (Powell, J., dissenting); Little Rock Sch. Dist. v. Pulaski County Special Sch. Dist., 778 F.2d 404, 436 (8th Cir. 1985); Ross v. Houston Indep. Sch. Dist., 699 F.2d 218, $222-$ 24 (5th Cir. 1983); Berry v. Sch. Dist., 698 F.2d 813, 819-20 (6th Cir. 1983); Paul Gewirtz, Choice in the Transition: School Desegregation and the Corrective Ideal, 86 COLUM. L. REV. $728,781 \mathrm{n} .179$ (1986) (emphasizing the practical impact of Liddell, noting that by 1986 approximately 7,000 black students had transferred from St. Louis schools to suburban schools, about one-fourth of the students who were attending all-black schools in St. Louis, and about 540 white suburban students had transferred to St. Louis schools).

48. Women served in the armed forces only as nurses until World War II, when they began serving in various auxiliary corps. Charles C. Moskos, From Citizen's Army to Social Laboratory, 17 WILSON Q. 90 (Winter 1993). The auxiliary corps were sex-segregated in their barracks and for purposes of administration and promotion, but they went to work with men in regular units. In this sense they enjoyed greater integration than African-American soldiers in the time of race-segregated units. Women served primarily in administrative, clerical, and health-care positions until 1973, when the abolition of the draft created some scarcity in personnel. See William N. Eskridge, Jr. \& NAN D. Hunter, Sexuality, GENDER, AND THE LAW 343 (1997). In 1978, women's integration in the military gained further ground when Congress eliminated the separate women's auxiliary corps, permitting women to join all branches of the military and fill all roles save those involved in direct combat. See id. at 346.

49. Like gay men and lesbians, African-Americans have always fought for this country (including the war for independence, before this country was a country). SHILTS, supra note 13 , at 7 ("Even before the armed forces of the United States were formally organized, gays 
The objections to racial integration of the armed forces bear striking similarity to the anti-gay rhetoric that currently supports the ban on gays in the military. ${ }^{50}$ For example, in the Civil War, some Union generals "feared that the presence of black soldiers in the army would create disharmony and drive away white volunteers." ${ }^{51}$ In 1940, Admiral W.R. Sexton wrote to the Secretary of the Navy that if "colored men" served in the Navy, "team work, harmony, and ship efficiency [would be] seriously handicapped" because of the attitudes of white sailors. ${ }^{52}$ As late as 1971, Lieutenant General Edward Almond wrote that racial integration "weakens" the "efficiency" of the armed forces. ${ }^{53}$ As in the case of homosexuality, unit cohesion served as a general objection to the integration of the service by race.

From nominal exclusion we moved (as in education) to a regime of segregated inclusion. After the Emancipation Proclamation, black men were officially allowed to enlist in the Union army during the Civil War as part of the "United States Colored Troops." ${ }^{44}$ Four black units fought in the Indian wars of $1870-90$, and black soldiers also fought in Cuba, where they rode with Teddy Roosevelt as part of the Rough Riders. ${ }^{55}$ Racial segregation within the army continued during World War I and at the start of World War II. ${ }^{56}$

were bearing arms for the yet unborn nation."). Initially, black enlistments were officially forbidden by order of the Council of Generals. John Sibley Butler, Race Relations in the Military, in THE MILITARY: MORE THAN JUST A JOB? 118 (Charles C. Moskos \& Frank R. Wood eds. 1988). The British offered the black men freedom if they would join the British ranks. In response, General George Washington told the Continental Congress that he would enlist black men notwithstanding the official prohibition, and this resulted in over five thousand black men serving the Colonial side in the Revolutionary War. Id. Black men were allowed to fight and die for this country's independence, but when the fighting ended they were excluded from any ongoing participation within military institutions. Id.

50. Many high-ranking military officials acknowledge but explicitly refuse to entertain parallels between sexual orientation and race. Former Joint Chiefs of Staff Chairman Colin Powell, a retired four-star general, has said that "as an African-American," he is "well aware of the attempts to draw parallels between" the military's stance on homosexuality "and positions used years ago to deny opportunities to African-Americans." He says, however, that "[s]kin color is a benign, non-behavioral characteristic. Sexual orientation is perhaps the most profound of human behavioral characteristics. Comparison of the two is a convenient but invalid argument." 139 CONG. REC. 2210 (1993) (letter of May 8, 1992, from Colin L. Powell, Chairman of the Joint Chiefs of Staff, to Rep. Patricia Schroeder).

51. Kenneth L. Karst, The Pursuit of Manhood and the Desegregation of the Armed Forces, 38 UCLA L. REV. 499, 502 (1991).

52. ESKRIDGE \& HUNTER, supra note 48, at 332.

53. Id.

54. Butler, supra note 49 , at 118 . As had happened earlier with the Revolutionary War, when the fighting ended in the Civil War, black men were again excluded from ongoing participation in the military.

55. Id.

56. The Army set a maximum quota for black soldiers to correspond with the proportion of the general population that was black. The number of African-Americans in the service never approached this maximum, reaching $5.9 \%$ on the eve of Pearl Harbor and, at its 
But unlike education, the military moved directly from segregated inclusion to mandatory integration. When the U.S. suffered a shortage of combat personnel during WWII, platoons of black soldiers were ordered to serve in previously all-white companies, but this was not by choice of the black or white soldiers. This experimental combination was instead a move to mandatory integration, made complete with President Truman's Executive Order of 1948 officially outlawing segregation in the U.S. military. ${ }^{57}$ By the time the U.S. fought in Korea, black and white soldiers fought side by side without incident. ${ }^{58}$

Stepping back, we see that racial integration of the military was incremental, but it bypassed the voluntary integration stage that has been much more present in the evolution of educational integration. So the natural question arises whether voluntary integration is needed with regard to sexual orientation. If this stage could be bypassed with regard to race (and sex), maybe it could be bypassed with regard to sexual orientation as well.

Our answer is that the voluntary integration stage with regard to race might have been less needed because the military went through a stage of segregated inclusion that had sufficiently demonstrated the competence and valor of African-American soldiers. But if this is so, shouldn't we instead be embracing segregated integration (instead of voluntary integration) as the intermediate step to full integration?

The problem here is that segregated integration of gays and lesbians (even if we wanted it) is really not feasible. The idea of segregated inclusion for gays and lesbians would mean "gay-only" units which would parallel the "black-only" or "women-only" units of the past. As a practical matter, the military does not have the option of

highest during WWII, topping out at about $10 \%$ of total personnel. CHARLES C. MOSKOS, THE American EnListed MAN: The Rank and File in TODAY's Military 109-10 (1970). The black units were usually used for heavy-duty labor and not combat. Id. at 110 .

57. Exec. Order No. 9981, 13 Fed. Reg. 4313 (1948).

58. The history of racial integration in the other branches varied slightly from that of the Army. In 1947, when the Air Force was established as separate from the Army, it began its own movements toward racial integration, and by 1950 the Air Force was largely integrated. In the Navy, black sailors served during the Civil War, but in the early twentieth century restrictions were imposed on their service, and by 1920 all black men were barred from enlisting. In 1932, black men were permitted to join the Navy as stewards in the messman's branch, and in 1942, some general service openings were allowed in segregated harbor and shore assignments. In 1944, the Navy took initial steps toward integration by assigning a small number of black men to general service on an ocean-going vessel. After WWII, the Navy took major steps toward integration, but even in 1970, African-Americans accounted for only 4 to $5 \%$ of total Navy personnel. See MOSKOS, supra note 56, at 112-13. By 1995, African-Americans constituted roughly $17 \%$ of Navy personnel. U.S. CENSUS BUREAU, StatistiCAL ABSTRACT OF THE UNITED STATES 374 (1999) (Table 587: Department of Defense Manpower: 1950 to 1997). In the Marine Corps, policy evolved from total exclusion of African-Americans before WWII, to segregated units of "heavy-duty laborers, ammunition handlers, and anti-aircraft gunners" in 1942, to full integration in 1949-50. MosKOS, supra note 56, at 113. 
using a segregated inclusion strategy, because gay men and lesbians have the option of remaining in the closet and thereby "passing" as heterosexual people..$^{59}$ This passing strategy is generally not available to women or people of color. The closeting option means that any attempt to (exclude or) segregate on the basis of sexual orientation in an absolute sense is bound to fail..$^{60}$

The difficulty of passing in the context of race and the relative ease of doing so with orientation means that segregated inclusion could progress toward mandatory integration more effectively in the context of race than orientation. While black soldiers were able (actually required) to be "openly" black and simultaneously to demonstrate their abilities as soldiers, gay and lesbian soldiers have never had this opportunity. As soon as a soldier's orientation is known by her superiors, her resulting separation from the military prevents her from serving while openly gay. As Kenji Yoshino explains:

[T] he military has been careful to rely on stereotypes that gays cannot disprove through infiltration. Because these stereotypes rely on what "open" or visible homosexuals will do to a unit, an invisible homosexual cannot, by definition, disprove the stereotype until she comes out of the closet. At that point, of course, she is generally removed from the military and the stereotype remains largely uncontested. ${ }^{61}$

Thus, while racial integration could move directly from segregated inclusion to mandatory integration, the integration of sexual minorities may have to proceed with a different intermediate step to counter the effects of the closet. Voluntary integration suggests itself as a candidate in part because of the important role it has played and continues to play in the integration of public education.

Our inclusive command proposal in essence is suggesting that the military use voluntary integration as a substitute for segregated inclusion as the core intermediate step, a step the military was able to skip in the context of race. The voluntary integration stage, as the name suggests, permits every participant to choose, fully informed and free of coercion, whether to join or avoid the integrated group.

The history of racial and sexual integration suggests that potential demonstration effects of any system that creates segregated groups are not just hypothetical. For example, in 1977, the Army conducted a

59. As Kenji Yoshino has argued, however, in the military context this invisibility option is disempowering rather than helpful to gay and lesbian soldiers. See Yoshino, supra note 18, at 544 (noting that DADT simultaneously dampens the empowering aspects and amplifies the disempowering aspects of gay invisibility).

60. Perhaps the closest analog to segregated inclusion applicable to sexual orientation is the DADT policy currently in force. Just as segregated inclusion permitted the military to insulate white soldiers from the perceived threat or disruption of racial integration, so too DADT allows the military to include gay men and lesbians while at the same time shielding heterosexual soldiers from the knowledge that any given individual is gay.

61. Yoshino, supra note 18, at 554. 
series of experiments to determine at what level of participation (0$35 \%$ ) women would lower unit performance in combat and noncombat contexts. The Army found that women's participation had no adverse affect on unit performance, at least up to the $35 \%$ level tested. ${ }^{62}$ This same spirit of experimentation could be applied to test the relative performance of the inclusive and exclusive commands in both stages I and II.

The volunteerism of the inclusive command mobilizes the power of heterosexual allies - forcing them to decide whether they prefer to stand with the intolerant or the tolerant. Some heterosexuals might prefer not to make this choice, but when confronted with the decision, many - like the jurors in Twelve Angry Men - will step away from the table of bigotry.

The inclusive command strategy admittedly treats integration of the forces as an incremental process. It permits some service members to keep themselves apart (or, under the "don't ask, don't tell" policy, to persuade themselves that they are staying apart) from people they dislike. Such a system of separation would not offer a satisfying end point for any attempt to integrate gay and lesbian soldiers into the Military. But one of the central qualities of the inclusive command strategy is that it is a dynamic rather than static proposal - a means to an end rather than a goal in itself. Creating separate spaces (based upon the level of openness about homosexuality and people's preferences for that) can contribute to the overarching goal of ultimate, undifferentiated integration of the armed forces by sexual minorities.

Granted, inclusive commands might begin as much smaller entities than exclusive commands. As homosexuality gains growing acceptance in our society, however, the number of people opting for inclusive commands should increase. Over time, exclusive commands might shrink, eventually becoming a sort of vestigial organ, so dispensable that the costs of maintaining separate facilities would outweigh the military benefits. At that point, soldiers with the real "problem" - an inability or unwillingness to serve with fellow soldiers who are openly gay - would be subject to exclusion. In this dynamic version of integration strategy, the stigma eventually falls on soldiers who are prejudiced rather than those who are gay. This in turn might create incentives for soldiers to rid themselves of their prejudices, or at least put those prejudices aside when it is time to serve their country.

62. MAJ. Gen. JeANNe HOLM, USAF (Ret.), WOMEN IN THE MILITARY: AN UnFINISHED RevOlution 257-58 (rev. ed., Presidio Press 1992) (1982); ESKRIDGE \& HUNTER, supra note 48 , at $345-46$. 


\section{IMPLEMENTING THE INCLUSIVE COMMAND}

The foregoing analysis lays out the theoretical arguments for adopting the self-segregation of the inclusive command. But we did not delve into the details of implementation and a host of nitty-gritty inquiries: What should be the wording of the questions asked? What precisely should turn on the answers? Can the military effectively function with both inclusive and exclusive commands? And finally, will anyone actually opt for the inclusive command? It is to these practical questions that we now turn. In essence, we hope to have already convinced you that the idea has appeal. Here we try to answer the question: will it actually work?

\section{A. What Questions Should Be Asked?}

There are many different ways to frame the basic questions in stages I and II. And, as in other contexts, the framing can have important impacts on the way that people would respond. In stage I, we have suggested that the self-sorting question be phrased:

Would you prefer to serve in a command without any gay personnel?

But we might have framed the question in the affirmative instead: "Would you be willing to serve in a command with gay personnel?" Or "Would you volunteer to serve in a command with gay personnel?" These different phrases might tease out different levels of support. Some soldiers who wouldn't "volunteer" to serve with gays might nevertheless "be willing" to serve if asked. Many soldiers simply might not care whether their colleagues are gay or not. We have chosen to frame the question in the negative - as a way of partitioning those who have an affirmative desire to avoid gay colleagues from those who are merely neutral. We predict that soldiers who don't care or don't have a problem with gays will answer this question "no," and be channeled into the inclusive command.

One might argue that the phrasing will have little effect on the answers, because the soldiers will quickly see through the question and focus on what turns on it - whether they will be assigned to the inclusive or exclusive command. By this argument, the question itself becomes irrelevant, and you might as easily base assignments on the question, "Is the moon made of cheese?" But from the perspective of an individual soldier, what turns on her answer is importantly determined by how other soldiers answer the question. A soldier's perception of how many other soldiers are neutral about gay personnel versus how many affirmatively desire to serve alongside gays is likely quite different. Framing the question differently is likely to produce different focal points. We have chosen a frame that attempts to channel the truly intolerant toward the exclusive 
command, while channeling the tolerant and the indifferent toward the inclusive.

We have also considered whether the question should expressly respond to potential "tipping" anxiety of heterosexual soldiers. Some soldiers might be willing to serve in an inclusive command, but only if the proportion of the unit that is gay remained below a certain level. Even if heterosexual soldiers responded in the abstract that they were willing to serve with openly gay people, in actual practice they might feel differently. Each soldier might have a "tipping point" beyond which his enthusiasm for an inclusive command would wane.

For example, while some heterosexual soldiers would be happy to serve in a command where $10 \%$ of the soldiers were openly gay, they might be less comfortable in a command where $75 \%$ of the soldiers were gay. This could be true for a number of reasons. In the $75 \%$ command, heterosexual soldiers might fear that the ambiguity of the inclusive command would be reduced, and that observers would assume that any given individual within the unit is gay. Other heterosexual soldiers might worry that the atmosphere of the command would change somehow if the percentage of the unit that was gay exceeded a certain point. Between 10 and $75 \%$, however, the tipping point is unclear. At what point would the proportion of gay soldiers in the unit become so large that no heterosexual soldiers would wish to remain in the unit, thus rendering it a "gay command" rather than an "inclusive" one? Even heterosexuals who genuinely support gay rights might still avoid patronizing gay bars or vacationing in certain sections of Fire Island.

This tipping anxiety is of course related to the challenge of ambiguation. Some heterosexuals might be comfortable with letting their audience entertain the possibility that there is a $5 \%$ chance that they are gay, but would become very uncomfortable if the audience thought there was a $50 \%$ chance that they were gay. This tipping anxiety was vividly displayed on a plane trip we took to Boston. By chance, the flight included several dozen members of the New York City Gay Men's Chorus. The heterosexual men on the flight were in the minority and some seemed to go to unusual conversational lengths to disambiguate themselves.

Collective action problems of this type could make it difficult to form a truly inclusive command from the very outset; heterosexual soldiers might be unwilling to opt for this command unless they felt assured that a significant number of other heterosexual soldiers would do the same. Just as we might ask the maximum percentage of the command that could be gay within an integrated unit before tipping would occur, so too we could ask the minimum percentage that would have to be heterosexual in order to get it off the ground.

In stage $I$, the tipping problem might be suppressed because soldiers would be much less aware of the percentage of the command 
that is gay. The tipping problem in stage I might also relate to the size of the inclusive command. Especially early in the experiment, there may be fear among heterosexual soldiers that low total participation in the inclusive command will result in the assumption that only gay soldiers opted in. Thus, in stage I, total participation in the inclusive command will act as a proxy for what percentage of each command is gay, since that factor is unknown. Heterosexual service members may be hesitant to join an inclusive command unless the total participation in such commands comprises a substantial percentage of the military. This would combat the presumption that all the members are gay because there would just be too many. Many service members may assume that approximately $10 \%$ (the highest, but also most popular estimate) of the population is gay. The exact percentage of the military that is gay or lesbian is unknown. ${ }^{63}$ But if $20 \%$ of recruits joined the inclusive command, fears may be assuaged. This doesn't contradict the idea that every soldier has a specific theoretical tipping point. However, even if a particular soldier's theoretical tipping point were exceeded by the actual number of gay people in the command, he would not know this and thus would not engage in the "straight flight" that would cause the tipping to occur. On the other hand, the very fact that a soldier has a tipping point and cannot know when it has been exceeded might cause him to avoid the inclusive command altogether. Thus, the inability to measure the percentage of the command that is gay does not necessarily help the inclusive command to recruit heterosexual soldiers. What starts as a tipping problem becomes a recruitment problem - we don't have to worry about heterosexual soldiers tipping out of the command if they won't join it to begin with.

Some recruits might prefer to qualify their willingness to serve in the inclusive command by indicating that if the percentage of gay people exceeded a certain level $(10 \% ; 35 \% ; 50 \%$, for example), they would prefer the exclusive command. To these people, the military could offer conditional membership in the inclusive command; soldiers could specify their tipping point and would be free to transfer to the exclusive command if the number of gay people in the inclusive command exceeded their disclosed tipping point. However, a cascade effect might occur in such a system: when individuals at the $10 \%$ point are allowed to transfer, the command may as a result reach $35 \%$ gay, allowing more service members to transfer.

63. Some evidence suggests that gay men are equally represented, and lesbians overrepresented, in the military as compared to their numbers in the general population. See THEODORE R. SARBIN \& KENNETH E. KAROLS, DEF. PERSONNEL SECURITY RESEARCH AND EDUC. CTR., NONCONFORMING SEXUAL ORIENTATIONS AND MILITARY SUITABILITY at C-5 (1988); Judith Hicks Stiehm, Managing the Military's Homosexual Exclusion Policy: Text and Subtext, 46 U. MIAMI L. REV. 685 (1992). 
Moreover, this approach would be difficult to implement, because the stage I screening mechanisms proposed thus far do not ask (and under DADT cannot ask) about soldiers' sexual orientations, only their preferences with respect to the sexual orientations of their peers. Without a separate question that seeks to discover soldiers' sexual orientations, military officials could not know who was gay, making it impossible to tell when the maximum gay percentage had been reached.

For information gathering purposes, then, the army could administer an anonymous survey, asking each recruit to state his or her sexual orientation. Two problems immediately arise with such a survey: accuracy and legality. The results from any such survey might be wildly inaccurate. Promises of anonymity are often insufficient to induce truthful answers to questions about homosexuality. And directly asking the question would violate the "don't ask" portion of DADT.

But the army might get a more accurate count of gay and lesbian soldiers if it used a "randomized response" approach, in which respondents are instructed to privately flip a coin. If it is heads, they answer the question "Are you gay" truthfully; if it is tails, they answer the question "yes" no matter what the truth is. A "yes," in other words, does not require respondents to reveal anything about themselves, because only the individual soldier knows the result of the coin flip. But if $53 \%$ of 1000 respondents should answer yes, the military would have a good idea that $6 \%$ of the group was gay. ${ }^{64}$ This randomization preserves anonymity by giving the "yes" responders plausible deniability, but allows researchers to estimate the proportion of gays in the aggregate. ${ }^{65}$

64. In a 1991 study by Overlooked Opinions designed to discover the percentage of gay men who had tested HIV positive, researchers used both direct techniques (direct questions with promises of anonymity) and randomized response techniques. Of the respondents who were surveyed using direct methods, $4 \%$ said they were HIV positive. Of those surveyed using randomized response techniques, $11 \%$ said they were HIV positive. Press Release, Overlooked Opinions, Inc., Apples and Oranges [hereinafter Apples and Oranges] (on file with author).

65. Unfortunately, some researchers have found that respondents' aversion to homosexuality is so strong that they will even disobey instructions in order to avoid answering "yes" to a question about homosexual activity. In one study, the coin flip was actually observed by hidden camera, and $26 \%$ of respondents instructed to answer "yes" to the question "have you ever had a homosexual experience" disregarded the coin flip and answered "no." Apples and Oranges, supra note 64 (discussing survey methodologies and the variations in reported numbers of homosexuals). Such disregard for the instructions would cause the survey to underreport the number of respondents who were gay. A second problem with such a survey is that it might violate both the "don't ask" and "don't tell" portions of DADT. But to our minds, the randomization of the coin-flipping mechanism avoids a legal problem because the military does not solicit identifiable information about individual service members' sexual orientation. 
If this coin-flipping survey revealed that the number of gay people in the inclusive command had exceeded the tipping points of some members, then the army even in stage I could respond to "tipping" anxiety. It could offer transfers to soldiers who had expressed a discomfort with serving with too many gays. In this way, the army would manage tipping by keeping track of aggregate numbers; and it would not be necessary to know the orientation of any given soldier. ${ }^{66}$

Ultimately, we reject the idea of soliciting detailed discriminatory preferences from the troops, because it might tend to reify and reinforce the very preferences we are trying to obliterate. The military should take seriously the risk that "straight flight" will turn the inclusive command de facto into a segregated gay command. But the solution to the tipping problem is found in effective training, not catering to homophobia. Prior to assignment, every recruit could complete an information-rich training program which would describe the inclusive command. In this training program, recruits would learn that DADT's prohibition on asking about service members' sexual orientation prevents military officials from knowing ex ante the proportion of any command - inclusive or exclusive - that is actually gay or lesbian. Indeed, the military might consider posing the sorting questions to recruits after they have completed basic training, where the military already stresses unity and tolerance for difference. Recruits who opt for an inclusive command in stage I would accept that assignment on the premise that DADT would prevent gay and lesbian members of the command from identifying themselves. In stage II, recruits would join the inclusive command knowing that some of their fellow service members might come out as gay or lesbian. With time and effective training, it is possible that many heterosexual soldiers would internally adjust their tipping point upward.

\section{B. What Should Turn on the Answers?}

Arguably, the assignment given to a soldier who says he is willing to serve with gay people should have no special label at all; it should just be "the army." This complete integration is the ultimate goal of the inclusive command approach. As a first step, however, giving labels to the two different commands can help create the appropriate focal point for self-segregation of the tolerant and intolerant. Naming

66. In stage II, the army might try to manage tipping more directly by imposing a quota on the number of openly gay soldiers that were assigned to particular inclusive commands. But quotas are unlikely to be effective, because gay and lesbian soldiers could closet themselves in order to gain admission to the inclusive unit. And quotas would expose gay and lesbian soldiers to a new type of discrimination that ultimately rests on the discriminatory preferences of their colleagues, partially negating the goal of the inclusive command. 
the two commands is problematic, however. It could prove difficult to find word pairs that avoid any connotation of hierarchy or stigma.

But we should pause to consider whether the military should stigmatize those soldiers who opt for the exclusive command. Identifying and stigmatizing bigots is a worthy goal for reasons besides the recognition of gay rights. Research on anti-Semitism shows that people who express prejudice on the basis of one characteristic (such as religion) are likely to express prejudice on the basis of other characteristics as well (such as race or national origin). ${ }^{67}$ In an organization that relies upon soldiers' ability to work together and defend each other, prejudice can be costly. A soldier who is willing to express prejudice on the basis of sexual orientation may also be harboring prejudice on the basis of race or religion, not so willingly expressed (because such prejudices are less socially acceptable than homophobia). Soldiers who opt for the exclusive command might be inadvertently signaling an inability to work not only with openly gay people, but with people of diverse races, religions, or ethnic backgrounds as well. Soldiers who join an inclusive command, on the other hand - particularly heterosexual soldiers who do so - might in general be more tolerant of and receptive to differences within the ranks. This receptivity could foster greater unity in an already diverse military force.

There is, however, a serious risk attendant to any stigmatization of the exclusive command. Social attitudes, like sexual orientation, can be masked. If soldiers join an inclusive command not because they are comfortable serving with gay people, but because they wish to avoid the negative aspects of the alternative command, then some soldiers with anti-gay prejudice (people we might call "closeted bigots") could end up in an inclusive command. These closeted bigots could be bad for unit cohesion in the inclusive command. In stage $\mathrm{I}$, although DADT would prevent them from identifying gay or lesbian soldiers with certainty, they could nonetheless decrease morale by making derogatory remarks about gay men and lesbians. In stage II, in addition to harassing the soldiers who came out, the closeted bigots might seek somehow to pit heterosexual soldiers against openly gay soldiers within an inclusive command. If the inclusive command is to have its desired demonstration effect, then soldiers who are likely to display or foment anti-gay prejudice should be discouraged from joining it. Stigmatizing the exclusive command could drive some soldiers to an inclusive command who are not really "qualified" to join it. In this sense, the inclusive command has its own exclusive qualities, because it bars people who express anti-gay sentiment.

67. See Clark Freshman, Whatever Happened to Anti-Semitism? How Social Science Theories Identify Discrimination and Promote Coalitions Between "Different" Minorities, 85 CORNELL L. REV. 313 (2000). 
If we wish to avoid stigmatizing either of the commands, we should devise names that are parallel and politically neutral. But this could prove difficult. If the command admitting openly gay people is "inclusive," is the other command "exclusive"? The word exclusive sometimes connotes a kind of elitism or superiority. But other word pairs - "tolerant"/"intolerant"; "may ask, may tell"/"don't ask, don't tell", etc. - are also value laden. Labeling the divisions by number does not solve the problem, because the lower number will inevitably communicate priority or hierarchy. To avoid these problems, we could choose labels that are not descriptive in any real sense, such as animals ("cougar" command/"tiger" command) or colors ("green" unit/"red" unit).

And for parallel reasons, the substantive assignments and career opportunities of soldiers who opt for the exclusive command should not be impaired. The military should resist the urge to statistically discriminate against these intolerant soldiers, again because such discrimination is likely to cause them to suppress their true feelings. A reverse tipping problem in which all soldiers opted for the inclusive command in stage I would not be an improvement over the current system. Of course, at some level it will be difficult to avoid the politicization of choice. Just as judicial nominees are judged on their decisions to join restrictive clubs, candidates for the Joint Chiefs of Staff one day would likely be judged on whether they preferred to associate with the intolerant. The point here is that the military should to the extent practicable reduce and disconnect the career and social consequences of opting for one command or the other. Over time, any word that we give to the exclusive command is likely to become tainted by repeated connection to its unworthy substance. But the mechanism should at least begin by putting the commands on an equal and neutral footing.

Whatever the name attached to the inclusive command, it should be integrated rather than exclusively gay. Creating a "gay ghetto" within the military could more severely stigmatize the soldiers who join this unit, singling out the people who are not the sole or even the primary cause of the problems surrounding sexuality and the military. Given the hostility many feel toward homosexuality, a command that was exclusively gay could be vulnerable to hostile reactions from soldiers outside the unit, reactions that could range from a general lack of support to "fragging," in which service members fire on their own people with malicious motive. ${ }^{68}$ The presence of heterosexual soldiers within an inclusive command would help to dilute this effect, insulating gay and lesbian soldiers from the negative reactions they would likely engender in some fellow soldiers outside the unit.

68. The term "fragging" was popularized during the Vietnam War, when enlisted men would occasionally fire on their own junior officers. 
In her defense of the ban on gays in the military, Melissa WellsPetry argues that grouping or segregating soldiers by certain behaviors can be detrimental to their relationships with fellow soldiers:

This phenomenon already is observed in military culture when soldiers are grouped - in social not official terms - by behavior, or potential behavior, that is considered substandard for soldiering. These groups of soldiers frequently become a focal point for reinforcing the military identity of the larger group....

Desirable or not, this social phenomenon is a reaffirmation of the larger group's identity as "real" soldiers. Nevertheless, this social phenomenon clearly can go too far and result in divisiveness. Controlling this natural social phenomenon would be more difficult if soldiers were grouped by non-military behavior as a matter of official policy. ${ }^{69}$

The inclusive command system would group soldiers by their expressed willingness to serve with openly gay colleagues. This willingness would not be, in Wells-Petry's words, "non-military" or "substandard" behavior, but rather would be crucially tied to work as members of the armed services.

At this point it is important to remember the important role commanding officers can play in implementing strategies like the inclusive command. One might even enlist the support of "norm entrepreneurs" such as H. Norman Schwartzkopf, Wesley Clark, or Colin Powell. They might make clear that if they were called upon to answer the key question, simply on their own behalf, they would indicate a willingness to serve with gay and lesbian service members. Indeed, given their praise of gay and lesbian former service members, Schwartzkopf and Powell could likely express this personal view without contradicting their 1990's Congressional testimony on unit cohesion. If norm entrepreneurs were able to endorse the inclusive command as a good thing, such statements might play a role analogous to the Supreme Court's pronouncement in Brown, creating an environment conducive to voluntary integration efforts.

But even if the problems of tipping and stigma proved so intractable that the inclusive command became in actuality a gay command, we needn't conclude that the experiment has failed. Instead, we might see the gay command as an interim step (stage I.a., perhaps) toward an integrated inclusive command (probably renamed, in order to disrupt the signal that "inclusive" = "gay"), which in turn would be an interim step toward full integration. The process of integrating gay and lesbian soldiers would be broken into smaller increments, but the cause of gay rights would nonetheless move forward.

69. WELLS-PETRY, supra note 12, at 169-70. 


\section{Administrative Burdens}

The inclusive command system this Essay proposes would admittedly impose on military administrators additional layers of cost and procedure that could prove onerous. First, we must acknowledge the additional costs if the military attempted to implement an inclusive command system by creating two duplicative sets of resources - one for each type of command. The costs of keeping the inclusive and exclusive commands separate but indeed equal could be prohibitive.

The greater the administrative burden created by a dual-command system, the more difficult it becomes for the army to meet other demands on commanders' time and energy. The very process of determining the appropriate command for a new soldier, for example, would consume precious resources. If soldiers retained the option of moving from exclusive to inclusive commands (or vice versa), this too could impose additional administrative costs. While soldiers are trained to be flexible, able to adapt to new conditions and requirements, it is also a hallmark of military training that strong emphasis is placed on esprit de corps. Undue movement of personnel from one command to another could jeopardize unit cohesion in ways that a few openly gay soldiers staying in one place never would.

Military officials might also object that the division of soldiers into inclusive and exclusive units would be artificial and potentially temporary. If the soldiers were called to combat, it would be difficult, if not impossible, to maintain the separation of the two units. They might fight in coordinated or even combined fashion. Experiences of gay and lesbian soldiers who have served suggest, however, that the more exigent the circumstances under which soldiers are working, the less important anyone's sexual orientation seems to be. ${ }^{70}$ Perhaps at such times, particularly, unit cohesion turns not on personal characteristics, but on the extent to which troops can count on each other to fight effectively and rescue endangered comrades. Not coincidentally, the military has been willing to overlook members' homosexuality in order to maximize personnel in times of war. ${ }^{71}$ As

70. Cal Anderson, Army Specialist-6, recounts, "We were situated about a mile from the Viet Cong. Being that close to possible death, I think the people were a lot more tolerant of each other, and most people kind of looked out for each other. There wasn't a lot of fear of getting caught, exposed, or kicked out of the Army for any particular infraction." HUMPHREY, supra note 16, at 64. J.W. "Skip" Godsey, a former enlisted man and officer who served in the Army from 1967-70 and in the Navy from 1970-86, says, "[I]n combat you didn't really give a fuck what men did and what men didn't do.... It didn't make a ... difference whether he was black, white, queer, or straight ...."). Id. at 210.

71. See SHILTS, supra note 13, at 726-27 (noting that as part of a "stop-loss" policy designed to reduce discharges from the armed forces and ensure adequate manpower, reservists who admitted their homosexuality were told by commanders that "they did not care - the reservists would be mobilized like any other soldier"). But see Lou Chibbaro Jr., Navy 'Stop-Loss' Order Bars Gays, WASH. BLADE, Oct. 5, 2001 (on file with author) (reporting that the U.S. Air Force and Navy had instituted a "stop-loss" policy to limit 
the United States has coordinated peacekeeping efforts with other members of the United Nations and NATO, moreover, American troops have worked closely with soldiers from countries that permit openly gay people to serve. ${ }^{72}$

In the wake of the rulings by the European Court of Human Rights requiring Great Britain to include openly gay people in its military forces, ${ }^{73}$ such interaction can only increase. Britain has been the United States' greatest supporter in the war on terrorism declared in response to the terrorist attacks of September 11; the UK has also deployed thousands of troops in Iraq. Not only do gay soldiers serve this and other countries' interest in staffing at times of crisis, they may disturb the average heterosexual soldier less at such times than in peace times. Geoffrey Bateman and Sameera Dalvi studied openly gay, non-American service members who have served with Americans in multinational military units or operations. They concluded that U.S. personnel are able to interact and work successfully with acknowledged gay personnel from foreign militaries. Institutionally, they found, "neither NATO nor the United Nations has addressed the coordination of divergent policies concerning sexual orientation in an official manner, largely because these organizations are preoccupied with more pressing concerns, and because homosexual personnel are not seen as sources of tension, even for U.S. personnel."74 As studies like Bateman and Dalvi's multiply, military leaders will gain further assurance that inclusive and exclusive commands could be coordinated and even combined in times of crisis without sacrificing military effectiveness.

Although "unit cohesion" is the central rationale now for excluding openly gay and lesbian citizens from the military, commanders and commentators have from time to time cited other administrative rationales for the ban, such as health care costs and security risks. For example, Melissa Wells-Petry, a strong opponent of

discharges in wake of the September 11 terrorist attacks, but that discharges for violations of DADT would continue).

72. NAT'L DEF. RESEARCH INST., RAND CORP., MR-323-OSD, SEXUAL ORIENTATION AND U.S. MILITARY PERSONNEL POLICY: OPTIONS AND ASSESSMENT 11-12 (1993) [hereinafter RAND].

73. Lustig-Prean \& Beckett v. United Kingdom, App. Nos. 31417/96 \& 32377/96, 29 Eur. H.R. Rep. 548 (1999); Smith \& Grady v. United Kingdom, App. Nos. 33985/96 \& 33986/96, 29 Eur. H.R. Rep. 493 (1999); see also Philip Britton, Gay and Lesbian Rights in the United Kingdom: The Story Continued, 10 IND. INT'L \& COMP. L. REV. 207, 233 (2000) (detailing the court decisions which led to the new British policy of "don't ask, can tell"). Early reports indicate that the change has not been difficult to implement. See Sarah Lyall, Gays in the British Military: Ask, Tell and Then Move On, N.Y. TIMES, Feb. 10, 2001, at A1.

74. Geoffrey Bateman \& Sameera Dalvi, Ctr. for the Study of Sexual Minorities in the Military, Univ. of Cal., Santa Barbara, Multinational Military Units and Homosexual Personnel (Feb. 2004), at http://www.gaymilitary.ucsb.edu/Publications/2004_ 02_BatemanSameera.htm. 
gays in the military, has devoted many pages to detailed descriptions of the "sexual practices" of gay men and lesbians, at least in part ${ }^{75}$ to explain why health care costs may be greater for gay service members than for straight ones. Because she provides no analogously detailed description of the "sexual practices" of heterosexuals and the medical conditions resulting from that activity (including pregnancy), she fails to make the case that health care costs are likely to be particularly or uniquely high for gay and lesbian soldiers. Even if gay men or lesbians in the general population are prone to particular health problems, we lack evidence that gay and lesbian soldiers share these health care needs. And even if evidence suggested that gay and lesbian service members had up to now exhibited certain behaviors or health care needs, it is possible that soldiers in an inclusive unit would be different.

For example, even if gay soldiers' need for secrecy about their sexual orientation under DADT has created high stress levels and led to substance abuse or mental health problems ${ }^{76}$ it is possible that gay soldiers in the inclusive unit, with more support and less at stake in concealing aspects of their identity, would suffer significantly less stress and fewer stress-induced health problems. ${ }^{77}$ Although WellsPetry cites data suggesting that gay men and lesbians are vulnerable to certain types of sexually transmitted diseases, ${ }^{78}$ she cites no evidence that military gays would contract such diseases at a rate any higher

75. One suspects that another motivation for including this material is to shock or disgust readers. Some of the information about sexual practices seems fairly irrelevant to the question of military service. For example, Wells-Petry discusses in detail some rather exotic sexual habits found in only a small percentage of a select sample of gay men. See WELLSPETRY, supra note 12, at 101. More common activities she discusses - such as "oral-genital contact" - are also practiced by heterosexuals, see EDWARD O. LAUMANN ET AL., THE SOCIAL ORGANIZATION OF SEXUALITY: SEXUAL PRACTICES IN THE UNITED STATES 98-99 tbl.3.6 (1994), but Wells-Petry includes no information about sexually transmitted diseases among heterosexuals and the sexual practices that help to spread them. See William N. Eskridge, Jr., Hardwick and Historiography, 1999 U. ILL. L. REV. 631, 635 (1999) ("At least three-quarters of the straight population, including the President of the United States, have engaged in oral sex (many of them regularly), and almost a fourth have engaged in anal sex"). No doubt many readers of Wells-Petry's book would also be shocked and disgusted to read detailed accounts of some heterosexual sex. $C f$. WILLIAM IAN MILLER, THE ANATOMY OF DISGUST (1997) (describing the disgust heterosexual sex has engendered in many cultures).

76. See WELLS-PETRY, supra note 12 , at 114 (observing that gay men and lesbians are likely to suffer stress stemming from "secrecy, disapproval and often internalized shame").

77. This in turn could make these gay and lesbian soldiers even more productive than they are able to be under the "don't ask, don't tell" regime, where some energy is inevitably wasted in the effort to maintain the secrecy of their sexual orientation. See HUMPHREY, supra note 16, at 71 ("[T]hat energy to hide should be channeled in more positive ways.... It's too bad, and the military loses").

78. See WELLS-PETRY, supra note 12, at 102-10. 
than heterosexuals do within the military. ${ }^{79}$ Assuming that gay men and lesbians within the military resemble the gay and lesbian population generally, or that if allowed to serve openly they would behave in a manner consistent with studies of certain gay and lesbian populations, may be unfounded. An inclusive command would permit gay and lesbian soldiers to demonstrate not only the types of soldiers they can be, but also the specific costs and benefits which would be derived from their presence in the military.

The final point to be demonstrated by the inclusive command is that gay and lesbian soldiers would pose no increased risk to security. Although in recent years opponents of gays in the military seem to have abandoned this untenable rationale for exclusion, for some time common wisdom held that homosexuality made a person vulnerable to coercion or seduction into espionage activity. Closeted gay men and lesbians, it was said, would cooperate with hostile governments in order to protect the secret of their sexual orientation; even people who were open about their own sexual orientation might be more vulnerable if they wished to protect the identities of closeted sexual partners. ${ }^{80}$ Logic and evidence have proven this theory wrong. As a matter of logic, the inclusive command would greatly mitigate the danger that gay or lesbian soldiers would betray their country in order to protect the secret of their own sexual orientation, because in a stage II inclusive command, their sexual orientation would already be generally known or would not be a matter bearing on their careers if it were revealed. ${ }^{81}$ The evidence shows that gay men and lesbians are no more likely to betray their country than heterosexuals are. ${ }^{82}$

Just as voluntary, incremental integration can solve the "unit cohesion" problem, so too the inclusive command could demonstrate that these additional administrative rationales are unfounded. Some military warnings of increased administrative burdens are empirical claims unsupported by relevant data. The inclusive command system

79. Similarly, the ability to be open about their partners and significant others might make it easier for gay and lesbian soldiers to preserve monogamous relationships, thus reducing extra-curricular sexual activity and consequent vulnerability to sexually transmitted diseases, something Wells-Petry emphasizes.

80. See SHILTS, supra note 13, at 682.

81. We have argued, however, that even in an inclusive command soldiers might be out to some people but not others. They might be open about their sexual orientation with coworkers within the military but not, say, with their parents. Thus it is not the case that a member of an inclusive command has nothing to lose if someone were to threaten publicity about sexual orientation. Rather, one of the crucially destructive consequences of that revelation under the current system - discharge, often dishonorable, from the military could not be part of the threat delivered to a soldier in a stage II inclusive command.

82. See Melinda S. Cooper, Equal Protection and Sexual Orientation in Military and Security Contexts: An Analysis of Recent Federal Decisions, 3 LAW \& SEXUALITY 201 (1993) (noting that in 117 cases of espionage by U.S. citizens analyzed, only 7 of the defendants were gay or lesbian). 
creates an opportunity to gather relevant data. Only in this way can we determine the strength of these empirical claims masquerading as normative statements.

\section{But Will Anyone Join?}

Although behavior under changed norms can be difficult to predict, it is not unrealistic to think that a substantial number of heterosexual soldiers would opt for the inclusive command. Our position is that many non-gay people are looking for ways to stand up for the rights of gay, lesbian, and bisexual people. For supportive heterosexual people inclined to serve in the military, the inclusive command would provide yet another way to work for the equality of gay people.

Randy Shilts writes about Greg Teran, a heterosexual man who attended MIT with the help of an Air Force ROTC scholarship. Teran was troubled by the military's anti-gay policy. When assigned to do a full briefing on "any military-related issue" for an ROTC class, he "delivered a report to the fifteen other Air Force cadets and his unit commander arguing that the regulations banning gays should be rescinded." ${ }^{83}$ Teran eventually began to work for change, attending a national conference of organizers whose goal was the elimination of ROTC chapters from college campuses unless the Defense Department lifted the ban on gays. ${ }^{84}$ Teran once told a flight commander that his goal for military service was to "serve in an Air Force that did not discriminate on race, sex, or sexual orientation." 85

In his book, Honor Bound, Joseph Steffan writes that when he was expelled from the Naval Academy because of his homosexuality, his heterosexual friends were loyal supporters. ${ }^{86}$ Greg Teran and Steffan's friends give us reason to believe that some heterosexuals already in the armed forces would choose an inclusive command if it were an option. ${ }^{87}$ Moreover, it is possible that the existence of an inclusive

83. SHILTS, supra note 13 , at 732.

84. Id.

85. Id.

86. JOSEPH STEFFAN, HONOR BOUND: A GAY AMERICAN FightS FOR THE RIGHT TO SERVE HIS COUNTRY 157 (1992).

87. See id. As Shilts writes:

That young men like Greg Teran had taken up the cause indicated that among a segment of the young heterosexual population was the dawning awareness that something was wrong in the way society treated gays, and that they must help do something about it. It was surely not a social phenomenon, but it suggested a future in which homosexuals would not be altogether alone in their fight for social acceptance.

SHILTS, supra note 13 , at 732-33. 
command might draw people to the military who would otherwise forego service. ${ }^{88}$

Recent surveys suggest that public acceptance of gays and lesbians in the U.S. military has grown since DADT was first implemented. A 2000 study found that between 1994 and 1999, the percentage of Navy officers who "feel uncomfortable in the presence of homosexuals" decreased from $57.8 \%$ to $36.4 \%{ }^{89}$ An even more recent CNN/Gallup poll conducted in December 2003 found that $79 \%$ of all Americans believed that gay and lesbian service members should be able to serve openly in the military. Among respondents ages 18-29, the percentage was even higher: an astounding $91 \%$ supported the right of openly gay people to serve..$^{90}$ This last statistic is particularly important, since it reveals the views of the age group most likely to be serving in the U.S. military. If these trends continue, there may be reason to expect that a critical mass of service members would express a willingness to serve in an inclusive command.

\section{CONCLUSION}

This Essay proposes a new, incremental way to integrate sexual minorities into the U.S. military: "inclusive commands." Built on a system of voluntary self-assignment, the inclusive command and its counterpart, the exclusive command, would permit soldiers to sort by their attitudes toward homosexuality.

But is integration of the military really a worthy goal for gay rights advocates, allies, and policymakers? Certainly, many theorists have raised legitimate concerns about the ways the military reinforces patriarchy and constructs masculinity to the disadvantage of women and people of color. ${ }^{11}$ One might point out that exclusion from the military, especially combat, keeps openly gay people out of harm's way.

88. See Diane H. Mazur, A Call to Arms, 22 HARV. WOMEN's L.J. 39, 69 (1999) ("Those who choose not to participate can have a more powerful effect in creating an unrepresentative military than specific policies that limit or exclude....").

89. Associated Press, Polls Show Reduction Of Soldiers' Opposition To Gays (Aug. 7, 2001), available at http://www.gaymilitary.ucsb.edu/ResearchResources/PressClips/news8_7 _01.htm (citing study conducted by Major John W. Bicknell of the Naval Postgraduate $\bar{S}$ chool, Monterey, Cal.); see also Press Release, Center for the Study of Sexual Minorities in the Military, University of California, Santa Barbara, Polls Show Reduction of Soldiers' Opposition to Gays: New Surveys Examine Shifting Attitudes Among Military and Civilian Populations (Aug. 6, 2001), available at http://www.gaymilitary.ucsb.edu/PressCenter/press_ rel9.htm. (summarizing data from one study showing that only $37 \%$ of Army men and $16 \%$ of Army women "strongly opposed" to gay people serving in the military, and another study showing only "mild dislike" for gay people among male Marines).

90. Paul Johnson, Massive Support for Gays in Military Poll Shows, 365Gay.com (Dec. 24, 2003), at http://www.365gay.com/newscontent/122403militaryPoll.htm.

91. See, e.g., Karst, supra note 51, at 502-10. 
But focusing exclusively on the costs and dangers of military service ignores the fact that inclusion in the military carries with it undeniable advantages. These are twofold. First, military service confers symbolic value: it simultaneously demonstrates and creates patriotism and full citizenship. Second, service in the military carries with it material benefits: job training, education, health and retirement benefits, and political clout. It is not happenstance that military service is an important correlate with success when candidates run for public office.

"Don't ask, don't tell" is an inadequate means of giving gay men and lesbians access to these benefits. As many commentators and even a few judges have argued, the policy continues to impose on gay and lesbian service members burdens that heterosexual soldiers need not bear. Nominally in the service of preserving "unit cohesion," the DADT policy forces gay and lesbian soldiers to lie about themselves, to keep a part of themselves hidden from fellow soldiers, impeding the very honesty and intimacy that helps to forge strong bonds of friendship and loyalty. From the gay service members' perspective, then, DADT does greater damage to their honest relationships with fellow soldiers than candor about sexual orientation ever could.

Moreover, DADT does nothing to test the assumption that heterosexual soldiers are incapable of serving with openly gay soldiers. To move the debate further and break down these anti-gay assumptions, we must create an environment where the assumptions can be tested and proven to be unfounded.

The inclusive command would be one such environment. There, in stage I, gay and heterosexual soldiers could express their willingness to serve together. In stage II, lifting DADT in the inclusive command would allow them to make good on those representations. In the inclusive command, gay and heterosexual soldiers could show, with discipline and an eye toward duty, that they can work together. With the support of commanders who are behind the integrationist goals of the unit, soldiers could demonstrate that unit cohesion need not suffer in the presence of openly gay soldiers, that sexual tensions can be managed, and that privacy can be respected. In the process, much of the harm currently imposed by the DADT policy could be ameliorated.

The importance of this support from higher ranking officers cannot be overemphasized. As the RAND report concluded when it summarized its recommendations: "Any sense of experimentation or uncertainty invites those opposed to change to continue to resist and to seek to 'prove' that the change will not work." ${ }^{92}$ Although this Essay has referred repeatedly to the demonstration effects of the inclusive

92. RAND, supra note 72 , at xxix. 
command and the opportunities for gathering data that it offers, commanders would have to make clear to all service members that the new regime is not an "experiment," but rather a process which they support toward a final goal of full integration. Through the inclusive command, the armed forces could come one step closer to the ideal Judge Nickerson has described: "A Service called on to fight for the principles of equality and free speech embodied in the United States Constitution should embrace those principles in its own ranks."

93. Able v. United States, 968 F. Supp. 850, 865 (E.D.N.Y. 1997). 